\title{
pARTIDA DE LA JEFE RUTH MARINA QUIROZ
}

Juan Carlos González $\mathrm{Q}^{+++\dagger}$

Con profundo pesar para nosotros, nos deja la enfermera jefe Ruth Marina Quiroz Rivera, docente del Departamento de Medicina Comunitaria, Especialista en Salud Familiar y Magíster en Educación Sexual.

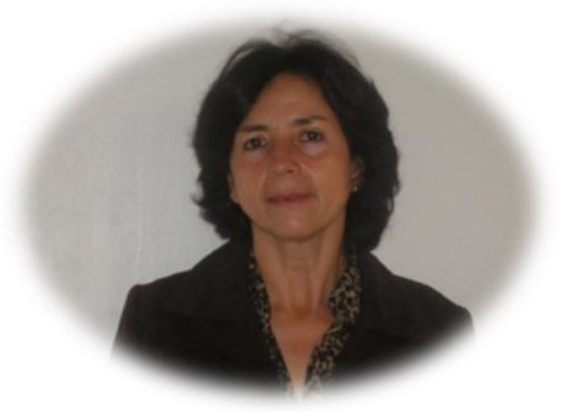

La jefe se ha pensionado y nuevos y diferentes planes reclaman su presencia en campos por completo diferentes a la academia. Durante estos 13 años nos ha dado un ejemplo de compromiso académico y asistencial inalcanzable. Diseñó, construyó y ejecutó un ambicioso proyecto de educación sexual para

los adolescentes dejándonos el reto de continuarlo, lo que reconocemos, va a ser bien difícil.
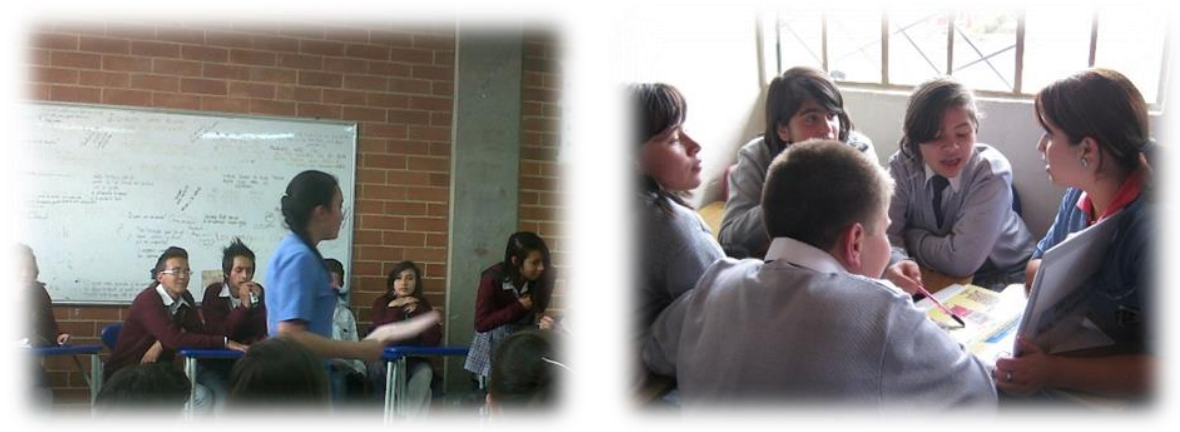

Todos sus compañeros la vamos a extrañar, pero nos alegra el corazón saber que todo lo que le espera está enmarcado en un bellísimo plan familiar.

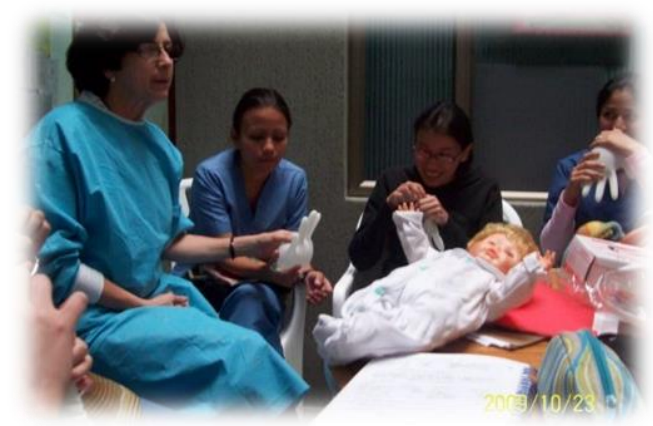

¡Dios quiera que tanto ella como nosotros descubramos formas donde aprovechemos toda la sapiencia que ella ha acumulado y que nuestros jóvenes tanto necesitan!

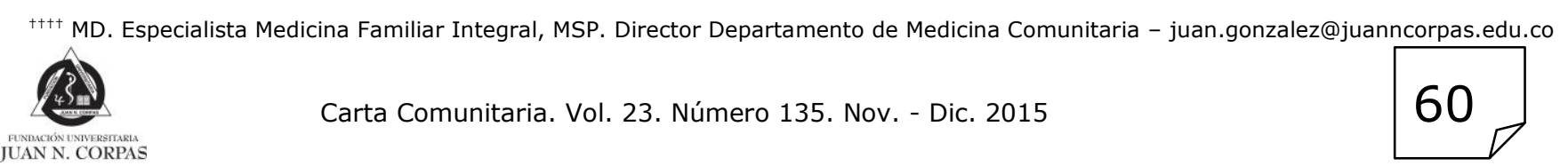

